\title{
Indirect effects of conifer release alternatives on songbird populations in northwestern Ontario
}

\author{
by John Woodcock ${ }^{1}$, R.A. Lautenschlager ${ }^{2}$, F. Wayne Bell ${ }^{2}$ and John P. Ryder ${ }^{1}$
}

\begin{abstract}
The effects of conifer-release alternatives on songbird densities (determined by territory mapping, mist netting, and banding) in four young (four to seven year old) spruce plantations were examined. Twenty to 38 (block dependent) species bred on each treatment block. Post-treatment data revealed no major treatment-related changes in breeding bird species composition. The mean density of all birds decreased from 6.9 pairs ha ${ }^{-1}$ pre-treatment, to 6.3 pairs ha ${ }^{-1}$ in the first post-treatment growing season $(P>$ $0.05)$. Mean densities of the 11 most common species increased by $0.35 \mathrm{ha}^{-1}$ on the control plots during the first post-treatment growing season, but decreased on treated plots by $1.1 \mathrm{ha}^{-1}$ (brush saw), $1.6 \mathrm{ha}^{-1}$ (Silvana Selective), $0.14 \mathrm{ha}^{-1}$ (Release ${ }^{\circledR}$ ) and 0.72 ha $^{-1}\left(V_{i s i o n}{ }^{8}\right)$. Following the conifer-release treatments, Chestnut-sided Warbler (Dendroica pensylvanica) had lower $(P<0.05)$ mean densities on the brush saw- and Silvana Selectivetreated plots than on the control plots and fewer $(P<0.05)$ female birds were captured in the first post-treatment year.
\end{abstract}

Key words: brush saw, Chestnut-sided Warbler, conifer-release, Fallingsnow Ecosystem Project, glyphosate, mist netting, Silvana Selective, songbirds, territory mapping, triclopyr

\section{Introduction}

Foresters commonly use conifer-release treatments to reduce angiosperm competition from around young, planted or naturally regenerated, conifers (Walstad and Kuch 1987). Because strong relationships exist between vegetation and avian community structure (Johnston and Odum 1956; MacArthur 1964; Morgan and Freedman 1986; Mills et al. 1991), habitat manipulations such as conifer-release, that drastically alter vegetation, should affect breeding bird populations. Most studies (Lautenschlager 1993) of the effects of coniferrelease treatments with herbicides on songbirds, however, found no significant, or minimal short-term effects, potentially because many lacked sufficient replicates, pre-treatment data, and/or controls; or because of songbird site tenacity (Wiens and Rotenberry 1985) and/or migrant deception (Lautenschlager 1993).

Here the results of the first two years of a longer-term study (Lautenschlager et al. 1997) are presented. Study objectives were to document the effects of a variety of conifer-release alternatives on songbird reproductive output and breeding and post-breeding season area use.

\footnotetext{
${ }_{1}^{1}$ Lakehead University, Biology Department, 955 Oliver Road, Thunder Bay, Ontario, Canada P7B 5E1.

${ }^{2}$ Ontario Ministry of Natural Resources, Ontario Forest Research Institute, P.O. Box 960, 1235 Queen Street East, Sault Ste. Marie, Ontario, Canada 6A 5 N5.
}

Les effets du dégagement des conifères sur les densités d'oiseaux chanteurs (déterminés par la cartographie du territoire, les nids et le bagage) pour quatre jeunes plantations d'épinette (de 4 à 7 ans) ont été étudiés. Vingt-deux à 38 espèces (dépendantes des blocs) se sont reproduites sur chaque bloc du traitement. Les données recueillies après le traitement n'ont indiqué aucune modification importante reliée au traitement dans la composition des espèces d'oiseaux d'oiseaux se reproduisant. La densité moyenne de tous les oiseaux a diminué passant de 69 couples ha-1 avant traitement à 63 couples ha ${ }^{-1}$ au cours de la première saison de croissance $(p<0.05)$ après traitement. Les densités moyennes de 11 des espèces les plus communes ont augmenté de $0.35 \mathrm{ha}^{-1}$ dans les parcelles témoins au cours de la première saison de croissance après traitement, mais ont diminué dans les parcelles traitées de $0.11 \mathrm{ha}^{-1}$ (scie débroussailleuse), $1.6 \mathrm{ha}^{-1}$ (Silvana Selective), $0.14 \mathrm{ha}^{-1}$ (Release $^{\circledR}$ ) et de $0.72 \mathrm{ha}^{-1}\left(\right.$ Vision $\left.^{\circledR}\right)$. Suite aux traitements de dégagement des conifères, la fauvette à flancs marrons (Dendroica pensylvanica) a connu dans les parcelles traitées des densités moyennes inférieures $(p<0.05)$ suite au traitement à la scie débroussailleuse et au Silvana Selective et moins de femelles $(p<0.05)$ ont été capturées au cours de la première année suivant le traitement.

Mots clés: scie débroussailleuse, fauvette à flancs marrons, dégagement de conifère, projet écosystémique de Fallingsnow, glyphosate, nids, Silvana Selective, oiseaux chanteurs, cartographie territoriale, triclopyr

\section{Methods}

\section{Area and Treatments}

The study area was located $60 \mathrm{~km}$ southwest of Thunder Bay, Ontario in the Great Lakes-St. Lawrence forest region (Rowe 1972). The area was clearcut and planted four to seven years before our study began. We used a randomized complete block design, with three white spruce (Picea glauca [Moench] Voss) and one black spruce (Picea mariana [Mill] B.S.P.) blocks of 28 to 52 ha each (Table 1), and the following operational (Bell et al. 1997a) conifer release treatments: (1) motor-manual release with brushsaws (mid-late October 1993); (2) mechanical release with the Silvana Selective/Ford Versatile (late October-early November 1993); (3) helicopter applied solutions containing Release ${ }^{\circledR 3}$ (a.i. triclopyr) herbicide (midAugust 1993); (4) helicopter applied solutions containing Vision $^{\circledR 4}$ (a.i. glyphosate) herbicide (mid-August 1993); and (5) control (no treatment). The blocks were selected to represent a range of site conditions typical of northwestern Ontario and commonly differed in aspect, slope, drainage, and soils (Simpson et al. 1997). The four blocks were separated by 1.3 to $3.0 \mathrm{~km}$ of mature forest.

\section{Territory Mapping}

Territory mapping described by Koskimies and Väisänen

\footnotetext{
${ }^{3}$ Trademark of DowElanco.

${ }^{4}$ Trademark of Monsanto.
} 


\begin{tabular}{lccccc}
\hline \multicolumn{6}{l}{ Table 1. Areas (ha) treated by treatment and block ${ }^{\mathbf{1}}$} \\
\hline Treatment & Block 1 & Block 2 & Block 3 & Block 4 & Total (ha) \\
\hline Control & 8.1 & 3.3 & 10.5 & 5.0 & 26.9 \\
Brushsaw & 6.0 & 4.7 & 12.4 & 4.4 & 27.5 \\
Silvana & 8.4 & 6.7 & 10.4 & 8.1 & 33.6 \\
Release & 4.9 & 6.5 & 8.1 & 9.3 & 28.8 \\
Vision $^{\circledR}$ & 9.9 & 6.5 & 10.4 & 5.3 & 32.1 \\
Total $^{\circledR}$ & 37.3 & 27.7 & 51.8 & 32.1 & 148.9 \\
\hline
\end{tabular}

'Based on Bell et al. (1997a).

(1991), and Ralph et al. (1993) was used pre- (1993) and post(1994) treatment, from late May to mid-July, to document species composition and territory density for birds that exhibited territorial behaviour on the blocks. Birds detected, aurally or visually, during repeated (10) visits were plotted (usually to within $5 \mathrm{~m}$ ) on field maps. To ensure that birds were likely not missed because of observer absence during a species-specific activity period, starting points for each replicate visit were changed to ensure that all parts of the blocks were visited at different times.

Observers from the adjacent halves of the same block compared data each morning to eliminate duplications. This comparison also helped identify possible discrepancies between observers. To further identify discrepancies, observers switched blocks on at least one occasion. After ten visits, an analysis of individual species maps revealed clusters of detections, and territories for individual birds heard singing on at least three visits (IBCC 1970) were assigned.

\section{Mist Netting}

Birds that bred on or used the blocks in the latter part of the breeding season and during the post-breeding season (early July through mid-August) were captured using mist nets and banded. The same net locations were used in pre- and posttreatment years. Nets were erected at first light each morning and taken down by 11:00 AM. Six to 20 nets were erected each day. Netting effort was rotated regularly among blocks, and was proportional to block size. Captured birds were identified, sexed, and aged using the methods of Pyle et al. (1987), then banded (aluminum numbered and plastic colour) during preand post-treatment years), measured (wing cord), and released.

\section{Post-spray Investigation}

Vision ${ }^{\circledR}$ and Release ${ }^{\circledR}$ herbicides used in this study were applied at nominal rates of 1.5 and $1.9 \mathrm{~kg}$ a.e. $\mathrm{ha}^{-1}$ respectively (Thompson et al. 1997). Thompson et al. (1997), in this volume, report that average deposit of the two herbicides at 3.5, 1.0 , and $0.5 \mathrm{~m}$ above ground was 60,25 , and $12 \%$ respectively. During the week following these applications (17-23 August 1993), herbicide treated plots were intensively searched for evidence of direct songbird mortality. Much time was spent searching for casualties, and one morning was spend capturing birds within the Release ${ }^{\circledR}$ treatment on block one.

\section{Vegetation}

Bell et al. (1997a), in this volume, document methods used and vegetation respones to these treatments.

\section{Statistical Analysis}

The number of territories of each bird species was calculated from the territory maps, and mean population densities were determined for each treatment in pre- and post-treatment years. These data were normally distributed, with the exception of a few outliers associated with vegetation anomalies, such as clumps of residuals missed by the treatments. Multiple analysis of variance (MANOVA) tests for completely randomized block design were used to evaluate differences in densities of the 11 most abundant species among treatments and blocks. Tukey's analysis was used to determine among-treatment differences. Paired $t$-tests were used to analyze differences in densities between years for each species summed for five treatments on four blocks. Regression analysis, comparing the number of territories determined from mapping with the number of males captured for each of the two years of the study, was used to evaluate territory mapping results. Frequency analysis was used to assess changes in the ratio of males to females captured in the 2 years. Minimum significance level was $P<$ 0.05 .

\section{Results}

Treatment-related differences in shrub densities, measured as percent cover and height among treatments were found (Bell et al. 1997a). Cover percentages of aspen and birch did not change significantly between years in the controls plots but were reduced in the treated plots. Untreated patches and missed strips of vegetation occurred within the cutting $(\sim 10 \%)$ and herbicide-treated $(25 \%)$ plots respectively.

\section{Territory Mapping}

Twenty to 38 species (block dependent) bred on each of the four blocks (Woodcock 1997). Territory densities for American Goldfinch (Carduelis tristis) and Cedar Waxwing (Bombycilla cedrorum) were not determined because they did not exhibit territorial behaviour until late in the season. Eleven species were common enough for statistical comparisons. Chestnutsided Warbler (Dendroica pensylvanica L.) was the most abundant (Table 2). Pre-treatment densities of five species differed among blocks, with most of the variability occurring on block four, a drier, more open site. In the post-treatment year, there were fewer block differences. In the pre-treatment year, only the density of Northern Flicker (Colaptes auratus) differed among designated treatment plots.

In the post-treatment year, the density of Chestnut-sided Warbler differed between the controls and the brush saw and Silvana Selective treatments $(P<0.05)$. Pre- to post-treatment decreases in the densities of Alder Flycatcher (Empidonax alnorum), Chestnut-sided Warbler (Fig. 1) $(P<0.05)$, Redeyed Vireo (Vireo olivaceus), and Veery (Catharus fuscescens) were noted on the cut (brush saw and Silvana Selective) plots (Table 2). Densities of Chestnut-sided Warbler and Mourning Warbler (Oporornis philadelphia) declined during the growing season after the herbicide (Release ${ }^{\mathbb{8}}$ and Vision ${ }^{(\mathbb{8}}$ ) treatments, with Mourning Warblers also declining in controls. A post-treatment increase in the density of White-throated Sparrows (Zonotrichia albicollis) was observed on Release ${ }^{\circledR}$ and Vision ${ }^{\circledR}$ plots, while Song Sparrow (Melospiza melodia) numbers increased on the Silvana Selective plots, and Lincoln's Sparrow (Melospiza lincolnii) increased on the Silvana Selective and Vision ${ }^{\circledR}$ plots (Table 2).

\section{Mist Netting}

In July and August of 1993 and 1994, 527 and 714 of the most common species of birds were banded, respectively 
(Table 3). Banding was terminated when it became evident that a large proportion of non-resident, non-territorial, birds were being captured. Densities mapped and individual males captured were highly correlated in both years $\left(r^{2} ; 0.71\right.$ [93], 0.91 [94]).

In the pre-treatment year 258 male and 154 female birds were captured (1.68 male female $\left.{ }^{-1}\right)$. In the post-treatment year 365 male and 149 female birds ( 2.45 male female $\left.^{-1}\right)$ were captured. There was a significant $\left(\chi^{2} .1=2.705\right)$ change in the sex ratios between years. The male to female ratio increased after treatment for Chestnut-sided Warblers from 1.6 to 2.6 (control), 2.7 to 13.0 (cut plots), and 2.4 to 5.8 (herbicide plots). The number of male Alder Flycatchers captured remained the same between years but the number of females captured declined by $50 \%$. The sex ratio did not change for White-throated Sparrow and Song Sparrow although the number of captures of both sexes doubled (Table 3 ).

\section{Discussion}

With the exception of Slagsvold (1977), no one has attempted to examine the effects of conifer-release alternatives on breeding songbird numbers. The net reduction in numbers of birds in our study was negligible, contrasting with Slagsvold's (1977) report of 30\% reductions in bird numbers. No major shifts in species composition of the bird communities using the treated plots were noted between pre- and post-treatment years. Freedman et al. (1988) reported similar findings. In our study only Chestnut-sided Warbler densities differed significantly between control and alternative treatments. Greatest reductions were on the cut (brush saw and Silvana Selective) treatments. Morrison and Meslow (1984) reported a similar response by Wilson's Warbler (Wilsonia pusilla), a species also associated with deciduous tree cover, to conifer-release with herbicides. Greenberg (1979) found that the Chestnut-sided Warbler was more highly stereotyped in its foraging repertoire than were other Dendroica species. Collins $(1981,1983)$ noted different requirements for song perches and nest sites among eastern warblers. Changes in these structures would affect the use of an altered habitat by a bird with a specific narrow niche. The cover percentage of aspen and birch did not change significantly between years in the controls, but was significantly reduced in the other treatments (Bell et al. 1997a). Changes in Chestnut-sided Warbler densities paralleled these treatmentinduced vegetation changes, and it is likely that lack of foraging plasticity resulted in the reductions observed.

Morrison and Meslow (1984) suggested that small patches of untreated vegetation scattered throughout a herbicidetreated area were sufficient to maintain an avian community similar to that on untreated areas. Probst et al. (1992) suggested that species dependant on shrubs would presumably be eliminated in stands where such vegetation was removed by herbicides or other means. Such 'clean' treatments, however, were rare in this study and sizeable pockets of shrubs remained in all treatments (Bell et al. 1997b). Such "skips" occur frequently in operational cutting treatments because shrubs are not removed where there are no crop trees, and operational aerial herbicide treatments commonly miss small areas within treated areas. The presence of untreated patches of vegetation in most treatments, however, helped maintain the diversity of the avian community.

The breeding densities of Alder Flycatcher, Chestnutsided Warbler, Mourning Warbler, Red-eyed Vireo, and

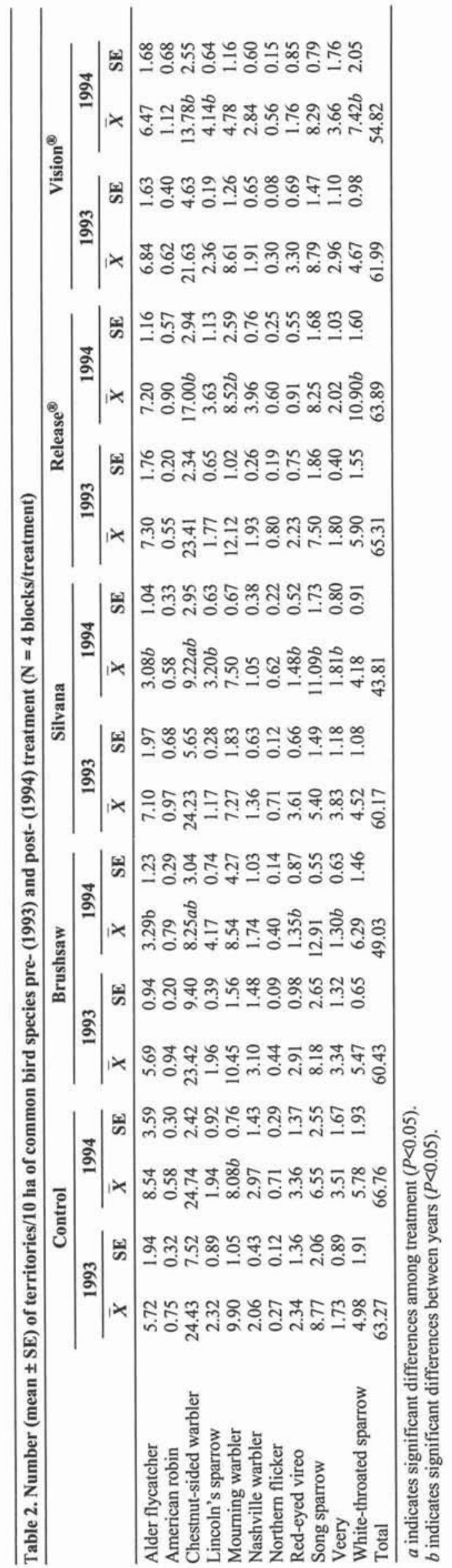




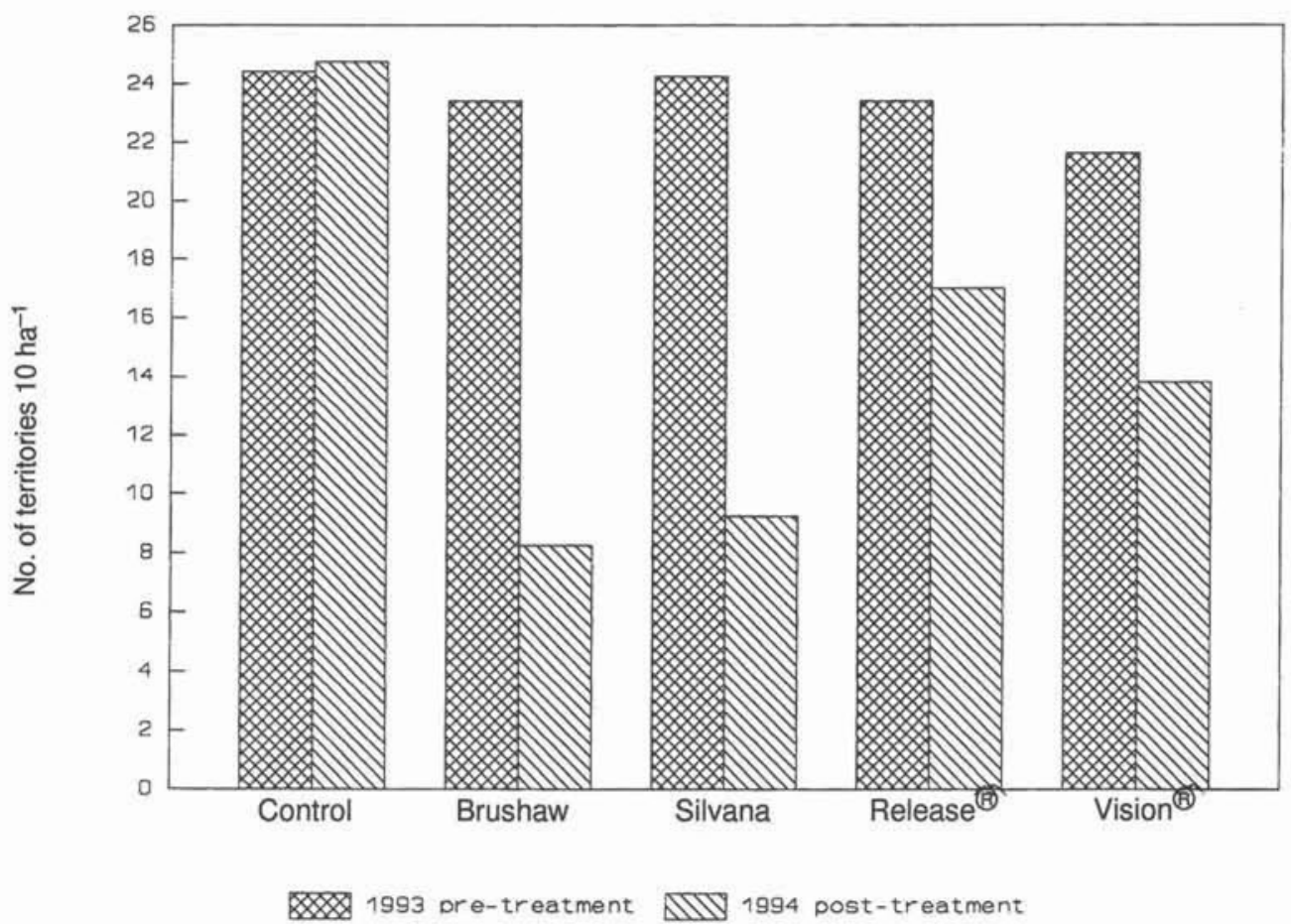

Fig. 1. Density changes in Chestnut-sided Warblers between years, among treatments.

Veery decreased after treatment in all treated plots. These reductions were greatest where the shrubs were physically removed (brush saw and Silvana Selective) because of the removal of foraging and nesting substrates. The reductions in breeding density of the five species were not as striking in the herbicidetreated plots, where although shrub foliage was reduced substantially, the physical structure of the defoliated stems remained. Beaver (1976) reported no shifts in abundance or breeding composition of breeding songbirds in herbicidetreated brushfields and suggested that the birds had responded to habitat structures that remained unchanged. Chestnutsided Warblers depend on dense shrubs for nest placement. Therefore the observed reductions should be expected in areas where shrubs have been removed, such as the brush saw and Silvana Selective treatments.

Songbird densities in the Release ${ }^{\circledR}$ and Vision ${ }^{\circledR}$ plots were most similar to the controls, suggesting that the structure of the remaining stems following herbicide treatments provided acceptable habitat. Lautenschlager (1993) proposed a "migrant deception" hypothesis: that birds arriving in the spring before foliation may occupy herbicide treated sites because they do not perceive that the stems are dead. This offers some explanation for the lack of response by breeding songbirds to the herbicide treatments; however, between years, male to female sex ratios increased for species whose densities decreased, whereas sex ratios remained the same for species whose densities increased. These results are consistent with the "female choice of mates" hypothesis proposed by Searcy (1979).

Stronger site fidelity in males has been reported in many passeriform species (Walkinshaw 1966a,b; Berger and Radabaugh
1968, Darley et al. 1977, Nolan 1978). Excess unmated males holding territories results in inflated breeding population estimates based on song counts. This unfortunate reality was supported by the higher proportion of males captured following these treatments.

MacKinnon and Freedman (1993) found that in the first posttreatment year, there were few declines in abundance of breeding birds. We concur with their suggestion that the census technique used (territory mapping) does not include a measure of breeding success. Our findings that the proportion of female birds in the population declined suggests that although breeding success may have been reduced, the reduction was masked by the sampling method - counting singing males. These observations reinforce the supposition that male site fidelity is an important factor affecting response to treatments, and interpretations of those responses.

These data suggest that in the first post-treatment growing season, the cutting treatments (brush saw and Silvana Selective), through removal of foraging and nesting habitat, have the most substantial negative effect on breeding songbird use of treated areas. Density reductions, however, were buffered by the presence of small untreated areas, that provided nest and foraging sites, within treated areas. Potential effects of different treatments on songbird abundance should be evaluated at a variety of scales; for instance, although Chestnut-sided Warblers and White-throated Sparrows are locally abundant they are species of concern (Thompson et al. 1992; Hussell et al. 1992). In the first post-treatment year, herbicide-treated plots maintained bird populations more similar to controls than cut plots. The three common sparrows on the plots responded favourably to the treatments. Conifer release with herbicides had no direct 
effect on most breeding songbirds one growing season after treatment.

\section{Acknowledgements}

We thank: Tom Baxter, Esther Board, and Anne Spoljarich for their dedication and hard work in the field; Peter F. Lee for statistical help, John Winters, Heather Barns, and Nikki Wood for help on-site, and Wendeline Price for editorial comments. This work was supported by the VMAP (Vegetation Management Alternatives Program) under the Sustainable Forestry Initiative, Ontario Ministry of Natural Resources, Sault Ste. Marie, Ont.

\section{References}

Beaver, D.L. 1976. Avian populations in herbicide treated brushfields. Auk 93: 543-553.

Bell, F.W., K.R. Ride, M.L. St-Amour and M. Ryans. 1997a. Productivity cost, efficacy, and cost effectiveness of motor-manual, mechanical, and herbicide release of boreal spruce plantations. For. Chron. 73: 39-46.

Bell, F.W., R.A. Lautenschlager, R.W. Wagner, D.G. Pitt, J.W. Hawkins and K.R. Ride. 1997b. Motor-manual, mechanical, and herbicide release affect early successional vegetation in northwestern Ontario. For. Chron. 73: 61-68.

Berger, A.J. and B.E. Radabaugh. 1968. Returns of Kirtland's Warblers to the breeding grounds. Bird Banding 39: 161-186.

Collins, S.L. 1981. A comparison of nest-site and perch-site vegetation structure for seven species of warblers. Wilson Bull. 93: 542-547.

Collins, S.L. 1983. Geographic variation in habitat structure of the Black-throated Green Warbler. Auk 100: 382-389.

Darley, J.A., D.M. Scott and N.K. Taylor. 1977. Effects of age, sex \& breeding success on site fidelity of Gray Catbirds. Bird Banding 48: 145-151.

Freedman, B., A.M. Poirier, R. Morash and F. Scott. 1988. Effects of the herbicide 2,4,5-T on the habitat and abundance of breeding birds and small mammals of a conifer clearcut in Nova Scotia. Can. Field-Nat. 102: 6-11.

Greenberg, R. 1979. Body size, breeding habitat and winter exploitation systems in Dendroica. Auk 96: 756-766.

Hussell, D. J. T., M. H. Mather, and P. H. Sinclair. 1992. Trends in numbers of tropical- and temperate-wintering migrant landbirds in migration at Long Point, Ontario, 1961-1988. pp. 101-114 In Ecology and conservation of neotropical landbirds. J. M. Hagan and D. W. Johnston (eds.) Smithsonian Institute Press. 609 p.

IBCC. 1970. International Bird Census Committee recommendations for an international standard for a mapping method in bird census work. Aud. Field Notes 24: 722-726.

Johnston, D.W. and E.P. Odum. 1956. Breeding bird populations in relation to plant succession in the Piedmont of Georgia. Ecology 37: $50-62$.

Koskimies, P. and R.A. Väisänen. 1991. Monitoring Bird Populations. Zoological Museum. Finnish Museum of Natural History. University of Helsinki. $143 \mathrm{p}$.

Lautenschlager, R.A. 1993. Response of wildlife to forest herbicide applications in northern coniferous ecosystems. Can. J. For. Res. 23: 2286-2299.

Lautenschlager, R.A., F.W. Bell, R.A. Wagner and J.A. Winters. 1997. The Fallingsnow Ecosystem Project: Comparing conifer release alternatives in northwestern Ontario. For. Chron. 73: 35-38. MacArthur, R.H. 1964. Environmental factors affecting bird species diversity. Am. Nat. 98: 387-397.

MacKinnon, D.S. and B. Freedman. 1993. Effects of silvicultural use of the herbicide glyphosate on breeding birds of regenerating clearcuts in Nova Scotia. J. Appl. Ecol. 30: 395-406.

Mills, G.S., J.B. Dunning and J.M. Bates. 1991. The relationship 
between breeding bird density and vegetation volume. Wils. Bull. 103: 468-479.

Morgan, K. and B. Freedman. 1986. Breeding bird communities in a hardwood forest succession in Nova Scotia. Can. Field Nat. 100: 506-519.

Morrison, M.L. and E.C. Meslow. 1984. Response of avian communities to herbicide-induced vegetation changes. J. Wildl. Manage. 48: 14-22.

Nolan, V., Jr. 1978. The ecology and behaviour of the Prairie Warbler Dendroica discolor. Ornithol. Monogr. 26: 1-595.

Probst, J.R., D.S. Rakstad and D.J. Rugg. 1992. Breeding bird communities in regenerating and mature broadleaf forests in the USA Lake States. For. Ecol. Manag. 49: 43-60.

Pyle, P., S.N.G. Howell, R.P. Yunick and D.F. DeSante. 1987. Identification guide to North American passerines. Bolinas, CA: Slate Creek Press. 279 p.

Ralph, C.J., G.R. Geupel, P. Pyle, T.E. Martin and D.F. DeSante. 1993. Handbook of Field Methods for Monitoring Landbirds. Gen. Tech. Rep. PSW-GTR-144. Albany, CA: Pacific Southwest Research Station, USDA For. Serv. 41p.

Rowe, J.S. 1972. Forest Regions of Canada. Can. For. Serv., Ottawa, Ontario Publ. No. 1300. 172p.

Searcy, W.A. 1979. Female choice of mates: a general model for birds and its applications to red-winged blackbirds (Agelaius phoenicus). Am. Nat. 114: 77-100.

Simpson, J. A., A. M. Gordon, P. E. Reynolds, R. A. Lautenschlager, F. W. Bell, D.A. Gresch and D.A. Buckley. 1997. Influence of alternative conifer release treatments on soil nutrient movement. For. Chron. 69-73.
Slagsvold, T. 1977. Bird population changes after clearance of deciduous shrub. Biol. Conserv. 12: 229-244.

Thompson, F.R., S.J. Lewis, J. Green and D. Ewert. 1992. Status of Neotropical migrant landbirds in the Midwest: Identifying species of management concern. Presented at the National Workshop on the Status and Management of Neotropical Migrant Birds, held in Estes Park, CO, Sept. 21-25, 1992.

Thompson, D. G., D. G. Pitt, B. Staznik, N. J. Payne, D. Jaipersaid, R. A. Lautenschlager and F. W. Bell. 1997. On-target deposit and vertical distribution of aerially released herbicides. For. Chron. 47-59.

Walkinshaw, L.H. 1966a. Summer biology of the Traill's Flycatcher. Wilson Bull. 78: 31-46.

Walkinshaw, L.H. 1966b. Studies of the Acadian Flycatcher in Michigan. Bird Banding 37: 227-257.

Walstad, J.D. and P.J. Kuch. 1987. Forest Vegetation Management for Conifer Production. John Wiley \& Sons, New York. 523 p.

Wiens, J.A. and J.T. Rotenberry. 1985. Response of breeding passerines to rangeland alteration in a North American shrubsteppe location. J. Appl. Ecol. 22: 655-668.

Woodcock, J. 1997. Effects of manual, mechanical, and aerial herbicide conifer release on songbird populations in regenerating clearcuts. M.Sc. Thesis, Lakehead University. (in prep.). 